\author{
O.D. Kochkodan, V.I. Maksin, R.S. Boiko
}

\title{
FEATURES OF ADSORPTION OF BINARY MIXTURES OF CATIONIC AND NON-IONIC SURFACTANTS BY NON-POROUS CARBON SORBENT
}

\author{
National University of Life and Environmental Sciences of Ukraine \\ 15 Geroiv Oborony Str., Kyiv, 03041,Ukraine, E-mail: okochkodan@hotmail.com
}

\begin{abstract}
The adsorption of cationic hexadecylpyridinium bromide and non-ionic oxyethylated octylphenols (TX-45, $T X-100, T X-305)$ surfactants from their mixed solutions at non-porous hydrophobic carbon sorbent such as thermal graphitized carbon black has been studied. The molar fraction of oxyethylated octylphenols in the mixtures was 0.2 , $0.4,0.6$, and 0.8. The results have shown that the adsorption values of hexadecylpyridinium bromide depend on the total concentration of the surfactant and the composition of mixtures.

It has been found that the molar fraction of nonionic surfactants in the mixed adsorption layers at carbon black surface decreases in the series: $T X-45>T X-100>T X-305$. The regularities of the change in the surface activity of the surfactant mixtures at the solution-solid sorbent interface with an increase in the total surfactant concentration in the solution correlate with those for the solution-air system, but are more pronounced. The areas per hexadecylpyridinium bromide and the oxyethylated octylphenols molecules in the adsorption layer while adsorbing from their binary solutions are lesser than ones for the surfactants adsorption from their individual solutions, and smaller than the corresponding areas at the solution-air interface. These findings indicate the consolidation of the adsorption layer at the solid surface and confirm that the surfactants adsorb at carbon black surface as associates.
\end{abstract}

Keywords: adsorption, surfactants, binary mixtures, adsorption layer, graphitized carbon black

\section{INTRODUCTION}

Adsorption of surfactants at a solid-liquid interface has an important role in many prosesses such as ore flotation, oil extraction, household and personal care applications, in textile, cosmetic, food industries, biotechnology and water treatment $[1,2]$. In many cases, the employing of the surfactants mixtures is more beneficial than using of individual surfactants $[2,3]$. Therefore, understanding the main features of mixed adsorption of surfactants at solid surfaces is of vital importance for prediction the properties of the surfactant mixtures and their applications.

Nowadays, adsorption of the surfactants at carbon sorbents is a subject of numerous studies, but majority of the works in this area is devoted to investigation of the surfactant adsorption from single component solutions [4-6]. Currently the main research topics related to the surfactants mixtures are the development of theoretical approaches to describe the colloid-chemical interactions between the surfactants in the binary solutions. The processes of micelle formation in the bulk solution as well as adsorption at an air- solution interface attract great research attention [7-9]. As for a solid sorbent-solution interface, the studies were conducted mainly with hydrophilic sorbents [10-12].

With regards to non-polar hydrophobic sorbents, the adsorption of a mixture of nonionic and cationic surfactants on the surface of hydrophobic glass was investigated $[13,14]$. The authors of paper [13] studied the mutual influence of Triton X-305 and tetradecyltrimethylammonium bromide surfactants on their adsorption on the hydrophobic glass and the interfacial tension values at the solid-liquid interface. In the concentration region of $10^{-4}-10^{-3} \mathrm{M}$ it has been found a synergistic effect when the adsorption value from the surfactants mixtures exceeds the adsorption values from the individual surfactants solutions. The authors of study [14] investigated the effect of dodecylpyridinium bromide and Triton X-100 concentrations on the interaction energy of $\mathrm{SiO}_{2}$ particles. The synergetic effect is found in a wide range of concentrations at both the surfactant solution-air and the surfactant solution-hybrophobic solid interfaces. As for activated carbon, it was shown synergetic 
adsorption of surfactants due to electrostatic interaction of oppositely charged ions of anionic and cationic surfactants [15].

Ridaoui et al. [16] investigated the change in the charge of carbon black (CB) particles in mixed aqueous dispersions of polystyrenepolyethylene oxide copolymers and cetyltrimethylammonium chloride. It has been shown that the adsorption value depends on the surfactant type. Adsorption of the surfactant or polystyrene copolymer on $\mathrm{CB}$ surface leads to electrostatic or steretic repulsion of $\mathrm{CB}$ particles [16].

Ma and Xia [17] evaluated the stability of CB dispersions in mixed solutions of sodium dodecyl sulfate and ethoxylated nonylphenols. The authors showed the adsorption of the ionic surfactant to decrease in the presence of the nonionic surfactant.

Bossolelti et al. [18] studied adsorption of sodium polystyrene sulfonates and ethoxylated nonionic surfactants (NP-12, NP-40, NP-100) on the $\mathrm{CB}$ surface. For all surfactants used, adsorption isotherms of the Langmuir type and the negative values of adsorption energy were obtained. It was assumed that the polyethylene oxide chains of adsorbed non-ionic compounds had coil conformation on CB surface [18].

The purpose of this work is to study the features of adsorption of binary mixtures of cationic and non-ionic surfactants on a nonporous hydrophobic carbon sorbent such as graphitized CB.

\section{MATERIALS AND METHODS}

Cationic and non-ionic surfactants were used in the study. Non-ionic surfactants such as oxyethylated octylphenols of the molecular formula $\mathrm{C}_{8} \mathrm{H}_{17} \mathrm{C}_{6} \mathrm{H}_{4} \mathrm{O}\left(\mathrm{CH}_{2} \mathrm{CH}_{2} \mathrm{O}\right)_{n} \mathrm{H}$ with the degree of oxyethylation $n=5,9,10$ and 30 (Triton X-45, X-100 and X-305 (TX-45, TX-100, TX-305), and a cationic surfactant such as hexadecylpyridinium bromide $\left(\mathrm{C}_{16} \mathrm{H}_{33} \mathrm{NC}_{5} \mathrm{H}_{5} \mathrm{Br}\right)$ (HDPB) were obtained from Sigma-Aldrich (USA) and used as received.

Thermally graphitized CB with the specific surface area of $105 \mathrm{~m}^{2} / \mathrm{g}$, as was evaluated by BET method with argon adsorption, was used as a non-porous carbon sorbent. For removal of inorganic ash components, $\mathrm{CB}$ was treated with $2 \mathrm{M}$ solutions of $\mathrm{HNO}_{3}$ and with concentrated $\mathrm{HF}$ by the method, described previously [19]. The samples were washed out with distilled water until no traces of $\mathrm{NO}_{3}{ }^{-}$and $\mathrm{F}^{-}$ions in washing waters were detected, and dried at $105{ }^{\circ} \mathrm{C}$.

Determination of the critical micelle concentration (CMC) values in the surfactants solutions was carried out by using a tenziometric method, which is based on plotting of the dependence of the surface tension $(\sigma)$ versus the equilibrium surfactant concentration $(C)$. The $\mathrm{CMC}$ value of the surfactant is defined as the concentration which corresponds to the break point on the $\sigma(\ln C)$ plot.

Measurement of the surface tension was carried out by Wilhelmy method by balancing the platinum plate. The cleanliness of the plate was controlled by the surface tension of the bidistilled water $\left(\sigma=72.5 \mathrm{~mJ} / \mathrm{m}^{2}\right)$. The accuracy of the evaluation, which was based on the average data for 3-5 measurements, was $\pm 0.5 \mathrm{~mJ} / \mathrm{m}^{2}$.

To obtain adsorption isotherms, the solutions with different initial concentrations of the surfactants but at a constant sorbent loading were shaken at $6000 \mathrm{rpm}$. The solution volume was $0.025 \mathrm{dm}^{3}$. After reaching the adsorption equilibrium, the solutions were separated from the adsorbent by centrifugation. The equilibrium concentrations of Triton $\mathrm{X}$ surfactants in the solutions were determined by spectrophotometric method at $\lambda=274 \mathrm{~nm}$, while the concentrations of HDPB in the solutions were evaluated by twophase titration method [20]. The measurement errors did not exceed 1 and $3 \%$, respectively. Investigations of the adsorption kinetics have shown that the adsorption equilibrium in the aqueous solution of surfactant is achieved in $8 \mathrm{~h}$.

The specific adsorption value was calculated from the ratio:

$$
A=\frac{C_{o}-C_{e}}{m} V
$$

where $A$ is adsorption value $(\mathrm{mol} / \mathrm{g}), V$ is the volume of the solution $\left(\mathrm{dm}^{3}\right), m$ is CB loading in the solution $(\mathrm{g}), C_{0}$ and $C_{e}$ are the initial and equilibrium surfactant concentrations $\left(\mathrm{mol} / \mathrm{dm}^{3}\right)$.

The colloidal-chemical characteristics of the used surfactants were determined as described previously [21], and are presented in Table 1.

\section{RESULTS AND DISCUSSION}

Fig. 1 shows the adsorption isotherms of HDPB, TX-45, TX-100 and TX-305 surfactants from individual aqueous solutions on $\mathrm{CB}$ 
surface. Adsorption of HDPB and Triton X surfactants is due to hydrophobic interactions between alkyl radicals in the surfactant molecules and CB surface. These interactions are recognized as the main driving force that cause the surfactant adsorption at hydrophobic surfaces $[1,10,22-24]$.

As seen in Fig. 1, the adsorption isotherms of the surfactants in the studied concentration range are of the Langmuir type with a clearly defined plateau. Adsorption saturation for HDPB was achieved at a higher equilibrium surfactant concentration $(6.5 \mathrm{mmol} / \mathrm{l})$ than for Triton $\mathrm{X}$ (about $0.4 \mathrm{mmol} / \mathrm{l}$ ). The maximum adsorption value for Triton $\mathrm{X}$ surfactants increases with a decrease in the length of the polyoxyethyl chain of the surfactant molecules: $\mathrm{A}_{\mathrm{TX}-45}>\mathrm{A}_{\mathrm{TX}-100}>$

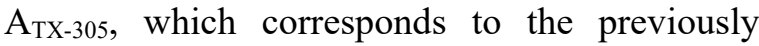
published data $[25,26]$. Earlier it was reported that the main parameter, which restricts the Triton $\mathrm{X}$ adsorption, is the polyoxyethylene chain protruded in the bulk solution [17]. The long polyoxyethylene chains could take a coil conformation in the solution $[25,27]$ and therefore restrict the packing density of the molecules in the adsorption layer, thus reducing the adsorption value.

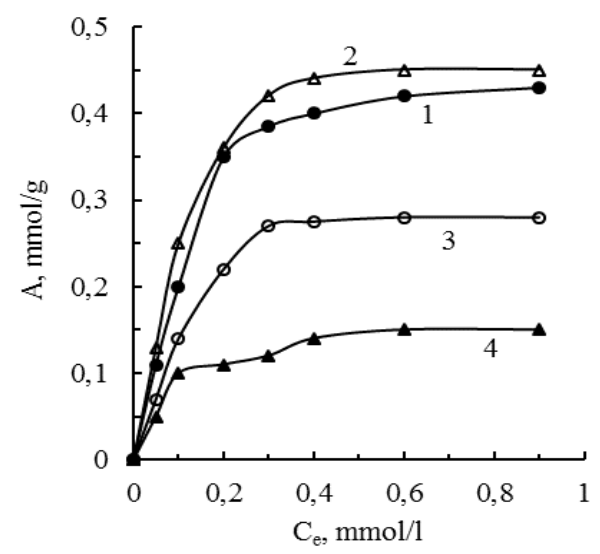

Fig. 1. Adsorption isotherms of HDPB (1), TX-45 (2), TX-100 (3) and TX-305 (4) on CB surface from individual surfactant solutions

Fig. 2 depicts the adsorption isotherms of HDPB at CB surface from binary mixtures with TX-45 (a), TX-100 (b) and TX-305 (c) surfactants at different mole fractions of Triton $\mathrm{X}$ in the mixtures: $\alpha_{T X}=0.2,0.4,0.6$ and 0.8 . The results have shown that the adsorption values of HDPB from these mixtures depend on the total concentration of the surfactant and the molar fraction of Triton $\mathrm{X}$ in the mixture.

As seen in Fig. $2 a, b$, at a low HDPB content in the mixture $\left(\alpha_{T X}=0.8\right)$, adsorption of HDPB from the binary solutions on CB surface is low. With increasing of $\alpha_{H D P B}$, the maximum adsorption value of HDPB from the mixture is higher compared to the adsorption from the individual HDPB solution. This means that adsorption of cationic surfactant is increased in the presence of the molecules of the non-ionic surfactant. A similar effect was observed for the cetyltrimethylammonium bromide-Triton X-100 system at the mixture concentration, which corresponds to an unsaturated monolayer [28].
This effect is enhanced with increasing of the mole fraction of HDBP in the mixture from 0.2 to 0.6. The largest increase in the surfactant adsorption is observed at $\alpha_{H D P B}=0.6$, when its value reaches $0.50-0.63 \mathrm{~mol} / \mathrm{kg}$ in the studied concentration range and there is a tendency for its further increase.

Such results can be explained by the fact that the embedding of the molecules of the non-ionic surfactant in the mixed adsorption layer reduces the electrochemical repulsion between positively charged ions of HBPB. This leads to higher adsorption of the cationic surfactant from its mixture with the non-ionic surfactants than the one from the individual HDPB solution. The maximal effective balance of the acting driving forces of adsorption is realized at $\alpha_{T X}=0.4$, probably due to adsorption of both individual HDPB ions and mixed TX-HDPB aggregates.

To calculate the composition of mixed adsorption layers of the surfactants and parameters of intermolecular interaction between 
the surfactants, a phase separation model (the Rubin-Rosen approach) was used [2, 29]. According to this model, the coefficient of intermolecular interaction in the adsorption layer $\beta^{s}$ was estimated by using the equation:

$\beta^{s}=\frac{\ln \left(\alpha_{1} C_{12} / C_{1}^{0} \chi_{1}\right)}{\left(1-\chi_{1}\right)^{2}}$

where $\alpha_{1}$ is the molar fraction of surfactant 1 in the solution, $\chi_{1}$ is the molar fraction of surfactant

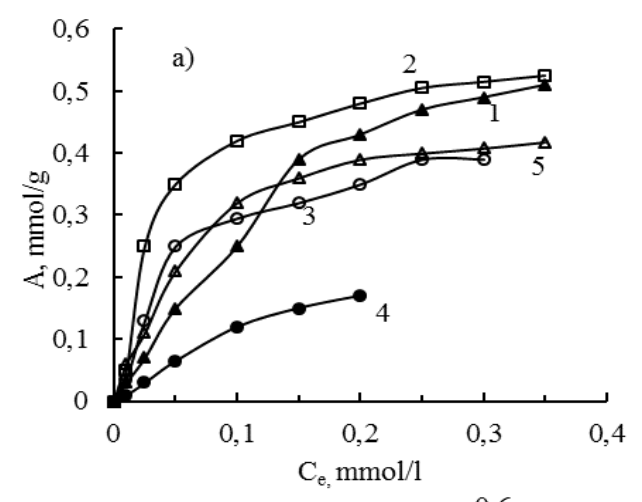

1 in the mixed adsorption layer, $C_{1}{ }^{0}$ and $C_{12}$ are the molar concentrations of the surfactant 1 solution and the binary mixture at the same adsorption value.

The composition of the adsorption layer was calculated by the ratio $[2,29]$ :

$$
\left(\chi_{1}\right)^{2} \ln \left(\frac{\alpha_{i} C_{12}}{C_{1}^{0} \chi_{1}}\right)=\left(1-\chi_{1}\right)^{2} \ln \left(\frac{\left(1-\alpha_{1}\right) C_{12}}{C_{2}^{0}\left(1-\chi_{1}\right)}\right)
$$

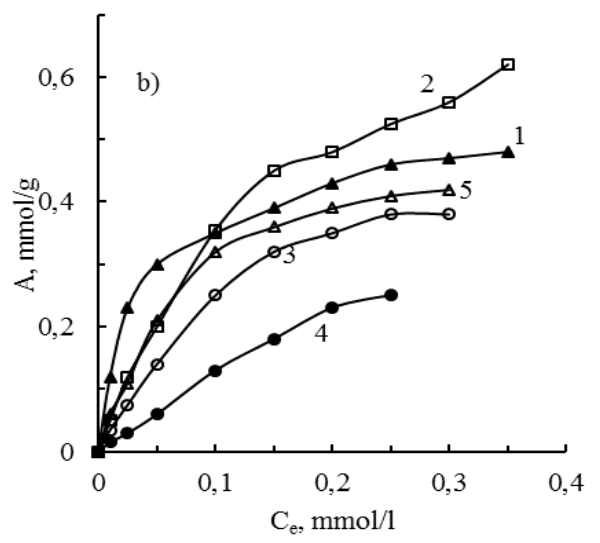

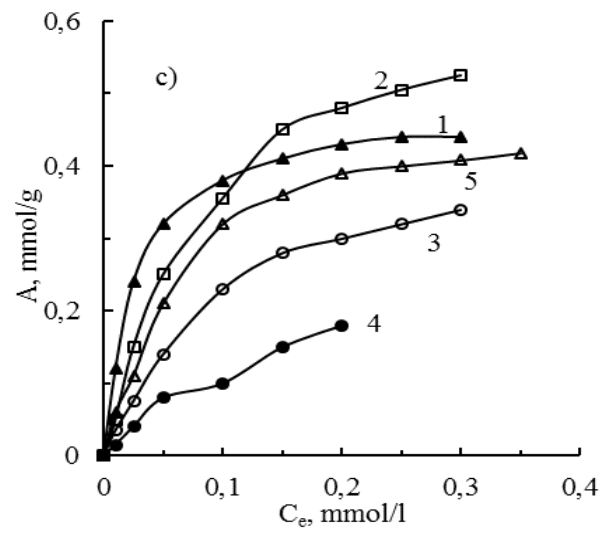

Fig. 2. Adsorption isotherms of HDPB at CB from single solution (5) and mixed solutions with TX-45 (a), TX-100 $(b)$ and TX-305 (c) at different mole fraction of Triton X $\left(\alpha_{T X}\right)$ in the mixtures: $\alpha_{T X}=0.2(1), \alpha_{T X}=0.4(2)$, $\alpha_{T X}=0.6(3), \alpha_{T X}=0.8(4)$

Thus, having determined from the experimental data the concentrations of the surfactant mixtures and the individual solutions, at which a given adsorption value is reached, the composition of the mixed adsorption layer at the specific adsorption value was calculated. The calculation results show (Table 1) that the composition of the adsorption layer on the $\mathrm{CB}$ surface is notably different from the surfactants ratio in the initial solution.

The $\chi$ values indicate that the mixed adsorption layers on CB surface are enriched with molecules of the non-ionic surfactants, even at their low content in the solution $\left(\alpha_{T X}=0.2\right)$. With increasing of the Triton $\mathrm{X}$ molar fraction in the binary solution from 0.2 to 0.8 its share in the adsorption layer increases by approximately 2.5 times.

Fig. 3 shows the ratio of the molar fraction of HDBP in the bulk solution and in the mixed adsorption layer on the $\mathrm{CB}$ surface. If the HDPB content at $\mathrm{CB}$ surface were the same as in the solution, the experimental data would fall in the dashed line in Fig. 3. However, as seen in Fig. 3, the non-ionic surfactants are present in excess on $\mathrm{CB}$ surface, and their mole fraction in the 
adsorption layer decreases in the following order: TX-45 $>$ TX-100 $>$ TX-305. These data indicate that more hydrophobic non-ionic surfactants are predominantly adsorbed on $\mathrm{CB}$ surface from mixed solutions with HBPB.

Negative values of $\beta^{s}$ interaction parameter (Table 1) indicate notable attraction of the surfactant molecules and ions in the mixed adsorption layers. An increase in the absolute value of $\beta^{s}$ parameters with increasing $\alpha_{\mathrm{TX}}$ in the solution characterize the strengthening of the interactions between the components in the adsorption layer. Fig. 4 shows the dependence of the coefficients of intermolecular interaction $\beta^{s}$ versus the mole fraction of TX-45, TX-100, and TX-305 surfactants in the mixtures. As seen in Fig. 4, an increase of $\alpha_{T X}$ value in the initial solution to 0.6 is accompanied by an increase in the absolute value of the coefficients $\beta^{s}$ at a fixed adsorption value. The strengthening of intermolecular interactions in the surface layer can be due to the formation of hydrogen bonds, as well as due to dispersion interactions between $\pi$-electrons of phenyl rings of the surfactant molecules and $\pi$-electrons of the graphite lattice of $\mathrm{CB}$.

Table 1. Parameters $\beta^{s}$ and molar fractions of Triton $\mathrm{X}$ in the mixed adsorption layers on the CB surface $\left(\chi_{T X}\right)$; $A=1.8 \times 10^{-4} \mathrm{~mol} / \mathrm{g}$

\begin{tabular}{|c|c|c|c|c|}
\hline$\alpha_{T X}$ & 0.2 & 0.4 & 0.6 & 0.8 \\
\hline \multicolumn{5}{|c|}{ HDPB/TX-45 } \\
\hline$\beta^{s}$ & -6.47 & -6.75 & -8.28 & -5.43 \\
\hline$\chi T X-45$ & 0.40 & 0.73 & 0.85 & 0.90 \\
\hline \multicolumn{5}{|c|}{ HDPB/TX-100 } \\
\hline$\beta^{s}$ & -5.61 & -5.22 & -7.53 & -4.80 \\
\hline$\chi T X-100$ & 0.30 & 0.55 & 0.73 & 0.76 \\
\hline \multicolumn{5}{|c|}{ HDPB/TX-305 } \\
\hline$\beta^{s}$ & -4.87 & -5.02 & -5.66 & -3.58 \\
\hline$\chi_{T X-305}$ & 0.52 & 0.24 & 0.68 & 0.70 \\
\hline
\end{tabular}

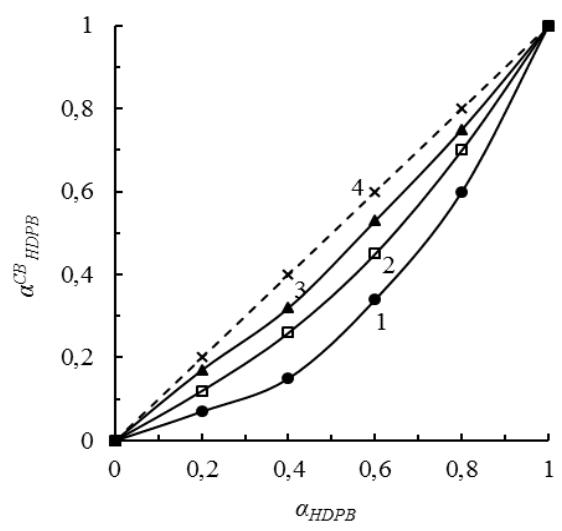

Fig. 3. Molar fraction of HDBP in the bulk solution $\left(\alpha_{H D P B}\right)$ and in the mixed adsorption layer on the CB surface $\left(\alpha^{C B}{ }_{H D P B}\right)$

Additional information related to the surfactant adsorption from binary solutions on the sorbent can be obtained by comparison with adsorption at an interface between a binary solution of the surfactant and air. Using the isotherms of the surface tension of the HDBB, TX-45, TX-100, TX-305 surfactants and their mixtures, which were previously obtained [20], the maximum adsorption values $\left(\Gamma_{\infty}\right)$ at the interface surfactant solution-air and the values of the area per the adsorbed surfactant molecule in mixed adsorption layer $\left(S_{\min }\right)$ were evaluated (Table 2).

By using the adsorption isotherms of the surfactants on CB (Figs. 1,2), the values of the maximal surfactants adsorption in the plateau region $\left(A_{\max }\right)$ were found. The area per molecule in the mixed adsorption layer at the CB surface was calculated by using the equation [30]:

$\omega=\frac{S}{A_{\max } N_{a}}$, 
where $S$ is the surface area of $\mathrm{CB}, \omega$ is a minimal area per molecule in the adsorption layer at $\mathrm{CB}$ surface, $N_{a}$ is the Avogadro number and $A_{\max }$ is the adsorption value at a concentration, which is close to saturation.

It is seen from the data presented in Table 2 that the surfactants adsorption values from their binary mixtures at the solution-CB interface significantly exceed the adsorption values at the solution-air interface. This is due to the formation of mixed HPDP-TX aggregates at CB surface, as well as due to hydrophobic interactions of the alkyl chains of the surfactant molecules with the nonpolar CB surface.

The areas per HDPB and the Triton $X$ molecules in the adsorption layer while adsorbing from their binary solutions are lesser than those for the surfactants adsorption from their individual solutions, and smaller than the corresponding areas at the solution-air interface (Table 2). These findings indicate the consolidation of the adsorption layer at the solid surface and confirm that the surfactants adsorb on $\mathrm{CB}$ surface as associates.

Table 2. Comparison of the main adsorption parameters of the surfactants mixtures at the solution-air and the solution-CB interfaces

\begin{tabular}{|c|c|c|c|c|c|c|}
\hline \multicolumn{7}{|c|}{ HDPB/TX-45 } \\
\hline$\alpha_{T X-45}$ & 0 & 0.2 & 0.4 & 0.6 & 0.8 & 1.0 \\
\hline $\begin{array}{l}\Gamma_{\infty} \times 10^{6} \\
\mathbf{m o l} / \mathbf{m}^{2}\end{array}$ & 2.76 & 3.64 & 5.01 & 6.72 & 4.13 & 2.66 \\
\hline$S_{\min }, \mathbf{n m}^{2}$ & 0.60 & 0.46 & 0.33 & 0.22 & 0.40 & 0.62 \\
\hline$A_{\max } \times 10^{6}$, & 3.81 & 6.35 & 8.26 & 9.74 & 7.18 & 4.29 \\
\hline$\omega, \mathbf{n m}^{2}$ & 0.43 & 0.26 & 0.20 & 0.17 & 0.23 & 0.39 \\
\hline \multicolumn{7}{|c|}{ HDPB/TX-100 } \\
\hline$\alpha_{T X-100}$ & 0 & 0.2 & 0.4 & 0.6 & 0.8 & 1.0 \\
\hline $\begin{array}{l}\Gamma_{\infty} \times 10^{6}, \\
\mathbf{m o l} / \mathbf{m}^{2}\end{array}$ & 2.76 & 3.38 & 4.80 & 5.71 & 3.90 & 2.51 \\
\hline$S_{\min }, \mathbf{n m}^{2}$ & 0.60 & 0.50 & 0.35 & 0.29 & 0.42 & 0.66 \\
\hline $\begin{array}{c}A_{\max } \times 10^{6}, \\
\mathrm{~mol} / \mathrm{m}^{2}\end{array}$ & 3.81 & 5.49 & 7.30 & 8.56 & 6.95 & 2.67 \\
\hline$\omega, \mathbf{n m}^{2}$ & 0.43 & 0.30 & 0.23 & 0.19 & 0.24 & 0.62 \\
\hline \multicolumn{7}{|c|}{ HDPB/TX-305 } \\
\hline$\alpha_{T X-305}$ & 0 & 0.2 & 0.4 & 0.6 & 0.8 & 1.0 \\
\hline $\begin{array}{l}\Gamma_{\infty} \times 10^{6}, \\
\mathbf{m o l} / \mathbf{m}^{2}\end{array}$ & 2.76 & 2.63 & 3.05 & 4.27 & 2.78 & 1.47 \\
\hline$S_{\min }, \mathbf{n m}^{2}$ & 0.60 & 0.63 & 0.54 & 0.39 & 0.60 & 1.13 \\
\hline$A_{\max } \times 10^{6}$, & 3.81 & 4.32 & 4.91 & 5.50 & 3.96 & 1.55 \\
\hline$\omega, \mathbf{n m}^{2}$ & 0.43 & 0.39 & 0.34 & 0.30 & 0.42 & 1.07 \\
\hline
\end{tabular}

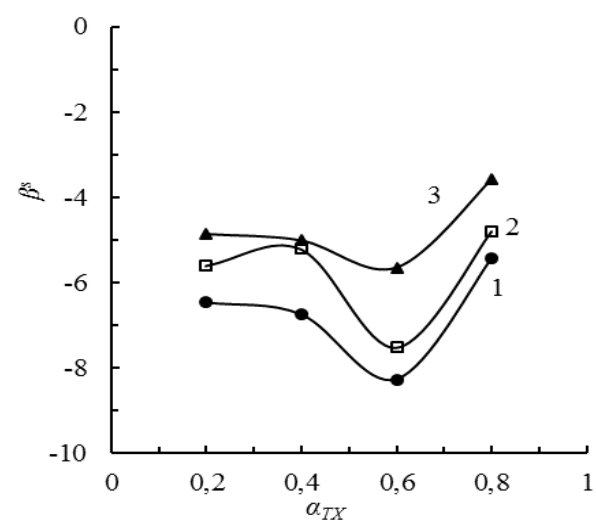

Fig. 4. Dependence of the coefficients of intermolecular interaction $\beta^{s}$ versus the mole fraction of TX-45 (1), TX-100 (2) and TX-305 (3) surfactants in the mixtures $\left(\alpha_{T X}\right) ; A=1.8 \times 10^{-4} \mathrm{~mol} / \mathrm{g}$ 


\section{CONCLUSIONS}

Adsorption of HBPB from its binary mixtures of different composition with TX-45, TX-100 and TX-305 surfactants at graphitized $\mathrm{CB}$ was studied. It has been found that at low surfactants concentrations, adsorption of HDPB from the surfactants mixtures is higher in the presence of the non-ionic surfactant than HDPB adsorption from its individual solutions. This can be explained by the fact that the inclusion of the molecules of the non-ionic surfactant in the mixed adsorption layer reduces electrostatic repulsion between charged hydrophilic groups of the cationic surfactants and thus promotes HDPB adsorption. It has been found that the mixed adsorption layers are enriched with molecules of the non-ionic surfactant. The molar fraction of the non-ionic surfactants in the adsorption layer decreases in the series: TX-45>TX-100>TX-305. The results obtained show that the more hydrophobic non-ionic surfactant is better adsorbed at $\mathrm{CB}$ surface from mixed solutions with cationic surfactant. The regularities of the change in the surface activity of the surfactants mixtures at the solution-CB interface with an increase in the total surfactant concentration in the solution correlate with ones at the solutionair interface, but are more pronounced. These findings indicates the consolidation of the adsorption layer at the solid surface and confirm the fact of the surfactants adsorb at CB surface as associates.

\title{
Особливості адсорбції бінарних сумішей катіонних і нейонних поверхнево-активних речовин непористим вуглецевим сорбентом
}

\author{
О.Д. Кочкодан, В.І. Максін, Р.С. Бойко
}

Національний університет біоресурсів і природокористування України вул. Героїв Оборони, 15, Київ, 03041, Україна, okochkodan@hotmail.com

\begin{abstract}
Досліджено адсорбиію катіонного гексадецилпіридиній броміду та нейонних оксиетильованих октилфенолів (TX-45, TX-100, ТX-305) із зміманих розчинів на непористому гідрофобному вуглецевому сорбенті - термічній графітованій сажі. Мольна частка гексадецилпіридиній броміду в сумішах становила 0.2, 0.4, 0.6 і 0.8. Результати показали, щьо величини адсорбиї гексадецилпіридиній броміду залежать від загальної концентрації поверхнево-активних речовин (ПАР) і складу сумішей.

Встановлено, щзо мольна частка нейонних ПАР в змішаних адсорбиійних шарах на поверхні графітованої сажі зменшується в ряду: TX-45> TX-100> TX-305. Закономірності зміни поверхневої активності сумішей ПАР на межі поділу рідина-твердий сорбент зі зростанням загальної концентрації ПАР в розчині корелюють з такими для системи рідина-повітря, але виражені сильніше. При адсорбиї ПАР на поверхні графітованої сажі з бінарних розчинів значення площуі, щзо займають молекули гексадецилпіридиній броміду $i$ оксиетильованих октилфенолів в адсорбійному шарі, менші, ніж при адсорбції з індивідуальних розчинів, $i$ менші відповідних площ на межі розділу фаз розчин - повітря. Це свідчить про ущільнення адсорбиійного шару на твердій поверхні $і$ підтверджує факт адсорбиії ПАР на поверхні графітованої сажі у вигляді acouiamis.
\end{abstract}

Ключові слова: адсорбчія, поверхнево-активні речовини, бінарні суміші, адсорбиійний шар, графітована сажа 


\title{
Особенности адсорбции бинарных смесей катионных и неионных поверхностно- активных веществ непористым углеродным сорбентом
}

\author{
О.Д. Кочкодан, В.И. Максин, Р.С. Бойко
}

Национальный университет биоресурсов и природопользования Украинь ул. Героев Обороны, 15, Киев,03041, Украина, okochkodan@hotmail.com

Исследована адсорбиия гексадециилиирдиний бромида и оксиэтилированных октилфенолов (TX-45, $T X-100, T X-305)$ из смешанных растворов на непористом гидрофобном углеродном сорбенте - термической графитированной саже. Мольная доля гексадецилпиридиний бромида в смесях составила 0.2, 0.4, 0.6 и 0.8. Результаты показали, что величины адсорбции гексадецилпиридиний бромида зависят от общей концентрации поверхностно-активных веществ (ПАВ) и состава смесей.

Установлено, что мольная доля неионных ПАВ в смешанных адсорбционных слоях на поверхности графитированной сажи уменьшается в ряду: TX-45>TX-100>TX-305. Закономерности изменения поверхностной активности смесей ПАВ на границе раздела жидкость-твердый сорбент с ростом общей конщентрации ПАВ в растворе коррелируют с таковыми для системы жидкость-воздух, но выражены сильнее. При адсорбции ПАВ на поверхности графитированной сажи из бинарньх растворов величина площади, занимаемой молекулами гексадецилпиридний бромида и оксиэтилированных октилфенолов в адсорбционном слое, меньше, чем при адсорбции из индивидуальных растворов, и меньше соответствующих площадей на гранище раздела фаз раствор - воздух. Это свидетельствует об уплотнении адсорбичонного слоя на твердой поверхности и подтверждает факт адсорбции ПАВ на поверхности графитированной сажи в виде ассоциатов.

Ключевые слова: адсорбция, поверхностно-активные веществва, бинарные смеси, адсорбционный слой, графитированная сажа

\section{REFERENCES}

1. Parfitt G.D., Rochester C.H. Adsorption from Solution at the Solid/ Liquid Interface. (London: Academic Press, 1983).

2. Rosen M.J., Kunjappu J.M. Surfactants and interfacial phenomena. (Hoboken, New Jersey: Jon Willey and Songs, Inc, 2012).

3. Chen L., Xiao J.X., Ruan K., Ma J.M. Homogeneous solutions of equimolar mixed cationic-anionic surfactants. Langmuir. 2002. 18(20): 7250.

4. Krivova M., Grinshpana D., Hedin N. Adsorption of CnTABr surfactants on activated carbons. Colloids Surf. A. 2013. 436: 62.

5. Lyu X., You X., He M., Zhang W., Wei H., Lia L., Heb Q. Adsorption and molecular dynamics simulations of nonionic surfactant on the low rank coal surface. Fuel. 2018. 211: 529.

6. Marsalek R., Pospisil J., Taraba B. The influence of temperature on the adsorption of CTAB on coals. Colloids Surf. A. 2011. 383(1): 80 .

7. Szymczyk K., Zdziennicka A., Krawczyk J., Janczuk B. Mutual influence of cetyltrimethylammonium bromide and Triton X-100 on their adsorption at the water-air interface. J. Chem. Termodyn. 2013. 59: 35.

8. Kochkodan O.D., Antraptseva N.M., Maksin V.I. Micelle formation and adsorption in aqueous solutions of binary mixtures Triton X-100 with dodecylpyridinium bromide and sodium dodecylsulfate. Ukr. Khim. Zhurnal. 2018. 84: 40. [in Ukrainian].

9. Ivanova N.I. Micellification and surface properties of aqueous solutions of binary mixtures of Twin 80 and cetyltrimethylammonium bromide. Vestn. Mosc. University. Chem. 2012. 53: 44. [ in Russian].

10. Zhang R., Somasundaran P. Advances in adsorption of surfactants and their mixtures at solid/solution interfaces. Adv. Colloid Interface Sci. 2006. 123-126: 213.

11. Woods D.A., Petkov J., Bain C.D. Surfactant adsorption kinetics by total internal reflection raman spectroscopy. 2. CTAB and Triton X-100 Mixtures on silica. J. Phys. Chem. B. 2011. 115(22): 7353.

12. Chang Z., Chen X., Peng Y. The adsorption behavior of surfactants on mineral surfaces in the presence of electrolytes - A critical review. Miner. Eng. 2018. 121: 66. 
13. Kostenko A.V., Soboleva O.A. Adsorption modification of a hydrophobic solid surface with solutions of surfactant mixtures. Vestn. Mosc. University. Chem. 2008. 49: 313. [in Russian].

14. Ivanova N.I., Parfenova A.M., Amelina E.A. The interaction of non-polar surfaces in solutions of mixtures of cationic and nonionic surfactants. Vestn. Mosc. University. Chem. 2007. 48: 182. [in Russian].

15. Xiao J.X., Zhang Y., Wang C., Zhang J., Wang C.M., Bao Y.X., Zhao Z.G. Adsorption of cationic-anionic surfactant mixtures on activated carbon. Carbon. 2005. 43(5): 1032.

16. Ridaoui H., Jada A., Vidal L., Donnet J.-B. Effect of cationic surfactant and block copolymer on carbon black particle surface charge and size. Colloids Surf. A. 2006. 278(1-3): 149.

17. Ma C., Xia Y. Mixed adsorption of sodium dodecyl sulfate and ethoxylated nonylphenols on carbon black and the stability of carbon black dispersions in mixed solutions of sodium dodecyl sulfate and ethoxylated nonylphenols. Colloid Surf. 1992. 66 (3): 215.

18. Bossolelti L., Ricceri R., Giabrielli G. The adsorption of polystyrene sulfonate and ethoxylated non-ionic surfactants at carbon black-water interface. J. Dispersion Sci. Technol. 1995. 16(3-4): 205.

19. Koganovskiy A.M., Levchenko T.M., Kirichenko V.A. Adsorption of Solutes Compounds. (Kyiv: Naukova dumka, 1977). [in Russian].

20. Kochkodan O.D., Maksin V.I., Antraptseva N.M., Semenenko T.S. Effect of pH and ionic strenth of solution on the colloidal-chemical properties of binary mixtures of surfactnts. Biological Resources and Nature Management. 2018. 10: 113. [in Ukrainian].

21. Tsubouchi M., Mitsushio H., Yarnasaki N. Determination of cationic surfactants by two-phase titration. Anal. Chem. 1981. 53(12): 1957.

22. Klimenko N.A., Karmasina T.V., Kochkodan O.D. Alteration of degree of water structuring and its influence on processes of micellization and adsorption of surfactants. Ukrainskij Khimicheskij Zhurnal. 2001. 67(1): 82.

23. Tiberg F., Brinck J., Grant L. Adsorption and surface-induced self-assemblyof surfactants at the solid -aqueous interface. Curr. Opin. Colloid Interface Sci. 1999. 4(6): 411.

24. Goncharuk V.V., Karmazina T.V., Slisenko V.I., Vasilkevich A.A., Kochkodan O.D., Valkovskaya N.I., Ivanitskii P.G., Krotenko V.T. Physical Chemistry of Water Treatment Processes-Effect of adsorptive treatment on the molecular-dynamic state of water. J. Water Chem. Technol. 2005. 27(6): 8.

25. Gellan A., Rochester C.H. Thermodynamics of adsorption of O-n-dodecylpentaethylene glycol and O-ndodecyloctaethylene glycol from aqueous solutions on to graphitised carbon. J. Chem. Soc., Faraday Trans. 1. 1985. 81(6): 1503.

26. Kochkodan O.D., Klimenko N.A., Karmazina T.V. Thermodynamic characteristics of adsorption of nonionic surfactants onto acetylene carbon black and ag-3 activated carbon. Colloid Journal of the Russian Academy of Sciences. 1996. 58(3): 330.

27. Levitz P.E. Non-ionic surfactants adsorption: structure and thermodynamics. C. R. Geosci. 2002. 334(9): 665.

28. Kochkodan O., Antraptseva N., Kochkodan V. Mixed adsorption of cetyltrimethylammonium bromide and Triton X-100 surfactants on carbon black. Mater. Sci. Forum. 2018. 936: 8.

29. Milton J. Rosen, Qiong Zhou. Surfactant-surfactant interactions in mixed monolayer and mixed micelle formation. Langmuir. 2001. 17(12): 3532.

30. Zhang R., Somasundaran P. Aggregate formation of binary nonionic surfactant mixtures on hydrophilic surfaces. Langmuir. 2005. 21(11): 4868. 